\title{
Can Ultrasonography-Guided Aspiration be an Alternative to Surgery in Wrist Ganglion Cysts?
}

\section{El Bilek Ganglion Kistlerinde Ultrasonografi Eşliğinde Aspirasyon Cerrahiye Alternatif Olabilir mi?}

\author{
Ensar Turko ${ }^{1}$, Sinan Oguzkaya ${ }^{2}$ \\ ${ }^{1}$ Department of Radiology, Sarkisla State Hospital, Sivas, Turkey \\ ${ }^{2}$ Department of Orthopedics and Traumatology, Sarkisla State Hospital, Sivas, Turkey
}

\begin{abstract}
Özet
Amaç: Mevcut çalışmanın amacı, el bilek ganglion kistlerinde açık cerrahi eksizyon ve ultrasonografi (USG) eşliğinde aspirasyon tekniklerinin klinik sonuçlarını ve rekürrens oranlarını karşılaştırmaktır.

Yöntem ve Gereçler: Ocak 2019 ve Ocak 2021 tarihleri arasında, el bilek ganglion kisti için USG eşliğinde aspirasyon ve açık cerrahi eksizyon uygulanan 46 hasta çalsşmaya dahil edildi. Aspirasyon uygulanan hastalar Grup A $(n=22)$, cerrahi uygulanan hastalar Grup S $(n=24)$ olarak adlandirldi. Hasta dosyalarından demografik veriler elde edildi. Son klinik takipte Disabilities of the Arm, Shoulder and Hand (DASH) skoru, rekürrens oranlar ve diğer komplikasyonlar kaydedildi ve gruplar arasında karșılaştırıldı.

Bulgular: Çalışmaya toplam 46 hasta dahil edildi (31 kadın, 15 erkek). Hastaların ortalama yaşı $33.6 \pm 11.9$ idi. Ort. Quick DASH skoru Grup S'de $11.25 \pm 2.90$ iken Grup A'da $11.90 \pm$ 2.70 idi. Rekürrens oranı Grup A'da daha yüksekti. Rekürrens görülen ve görülmeyen grupların klinik sonuçları arasında fark izlenmedi.

Tartışma ve Sonuç: Aspirasyon uygulanan hastalarda rekürrens oranı daha yüksekti fakat bu fark fonksiyonel skorlarda izlenmedi. Her iki tedavi grubu da benzer düzey fonksiyonel skorlarla iyileşmiştir. Sonuç olarak USG eşliğinde ganglion kist aspirasyonu cerrahiye alternatif bir tedavi seçeneği olarak kullanilabilir.
\end{abstract}

Anahtar Kelimeler: Ganglion kisti; ultrasonografi; cerrahi; rekürrens

\section{Introduction}

Ganglion cysts are the most common cause of swelling around the hand and wrist $(1,2)$. They are frequently diagnosed in females who are in their second or fourth decades. Ganglion cysts generally originate from the tendon sheath or joint capsule (3). Although the exact reason remains unknown,

\begin{abstract}
Inroduction: The purpose of the study was to compare the clinical results and recurrence rates of patients who received ultrasound (US) guided aspiration and open surgical excision for wrist ganglion cysts.
\end{abstract}

Materials and Methods: The 46 patients who received USguided aspiration and open surgical excision for wrist ganglion cysts between January 2019 and January 2021 were selected. Patients were divided into two according to choice of treatment. The patients who received aspiration were called Group A $(n=22)$, and the patients who received surgery were called Group S $(n=24)$. Patient characteristics were recorded from the patient files. At the last follow-up, recurrences were recorded, and the functional status of the patients was questioned by the Disabilities of the Arm, Shoulder, and Hand (DASH) Score. Complications other than recurrence were also analyzed.

Results: A total of 46 patients (31 female, 15 male) were included in the study with a mean age of $33.6 \pm 11$.9. The mean quick DASH score was $11.25 \pm 2.90$ in Group $\mathrm{S}$ and $11.90 \pm$ 2.70 in Group A. The clinical results were similar between the two groups; however, the recurrence rate was significantly higher in Group A. The recurrence did not affect functional outcomes.

Conclusion: The recurrence rates were higher in the aspiration group, but this difference did not cause a difference in functional status. As a result, us-guided cyst aspiration can be used as an alternative method to surgery.

Key Words: Ganglion cyst; ultrasonography; surgery; recurrence

it has been suggested that trauma might be associated with the etiology (4). Most of the cases are asymptomatic except for swelling. However, pain, paresthesia, and weakness can be seen in some patients (5). Joint motion can be affected as well, and ganglion cysts may enlarge, shrink, or disappear spontaneously, In asymptomatic cases, follow-up without intervention is recommended because $40-58 \%$ of the patients show spontaneous

\footnotetext{
*Sorumlu Yazar: Sinan Oguzkaya Sarkisla State Hospital, Department of Orthopaedics and Traumatology. Yildirim Mah. Alper Tunga Cad. Kalecity evleri B blok No: 6, 58400, Sarkisla, Sivas, Turkey. E-mail: sinanoguzkaya@hotmail.com Tel: +90 5374436776 Orcid: Sinan Oguzkaya: 0000-0003-3032-5714, Ensar Turko: 0000-0001-7989-5668
}

Geliş Tarihi:17.08.2021, Kabul Tarihi:24.11.2021 
resolution (6). Although most wrist ganglions are harmless, they may cause cosmetic concerns, pain, numbness, or weakness in some cases. Those cases are considered symptomatic and should be treated (7). Surgical treatment and ultrasound (US) guided aspiration are widely used treatment options for those patients (7-10). The main advantage of US-guided aspiration is that it is a less invasive and time-saving procedure with low risks of complications. On the other hand, high rates of recurrence are a significant concern after aspiration (11). Surgical excision is accepted as the gold standard method for ganglion cysts associated with lower recurrence rates and fewer complications. However, intraoperative nerve injuries can occur; some studies also reported persistent pain, paresthesia, and keloid formations after surgery $(6,12)$. This study compared the clinical results, recurrence, and complication rates of open surgical excision and US-guided aspiration in patients with ganglion cysts around the wrist.

\section{Materials and Methods}

This retrospective study was started after obtaining approval from Sivas Cumhutiyet University institutional review board (Approval date and Number: 26.05.2021/2021-05/33). The records of patients who received open surgical excision and US-guided aspiration for wrist ganglion cysts between January 2019 and January 2021 were selected. The inclusion criteria were: (1) $\geq 18$ years old at the time of intervention, (2) no previous interventions from the ipsilateral wrist, (3) follow-up time with a minimum of six months, (4) received open surgical excision of US-guided aspiration between January 2019 and January 2021. The exclusion criteria were: (1) ganglion cysts located other than the wrist $(n=4),(2)$ received another treatment (blind aspiration, aspiration with corticosteroid injection) $(n=6),(3)$ concomitant wrist pathologies (previous surgery, tendinitis, etc.) ( $n=4)$, (4) patients who received both treatments at different times $(n=3),(5)$ lost to follow-up $(n=1)$. A total of 64 patients' records were evaluated. After inclusion and exclusion criteria were applied, 18 patients were excluded, and 46 patients were selected for the study.

Surgical technique: The operations were performed under regional anesthesia with a tourniquet. The skin incision was carried out depending on the location of the cyst, and a longitudinal incision was carried out over the cyst. With careful dissection, the capsule's pedicle and capsular attachments were exposed, and the cyst was excised without rupturing the cyst whenever possible. The entire cyst complex, including cyst, cyst pedicle, and the insertion of the cyst to the joint capsule, was removed while avoiding adjacent neurovascular structures (Figure 1).

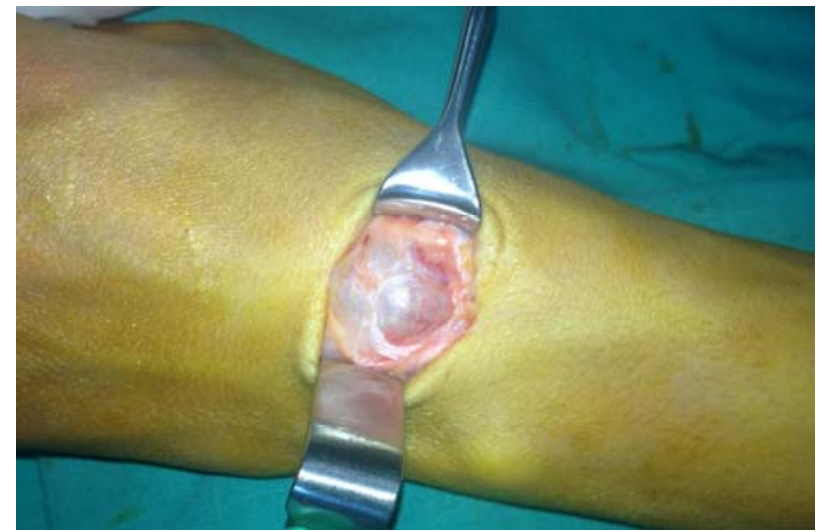

Figure 1. Intraoperative view of a dorsal wrist ganglion cyst

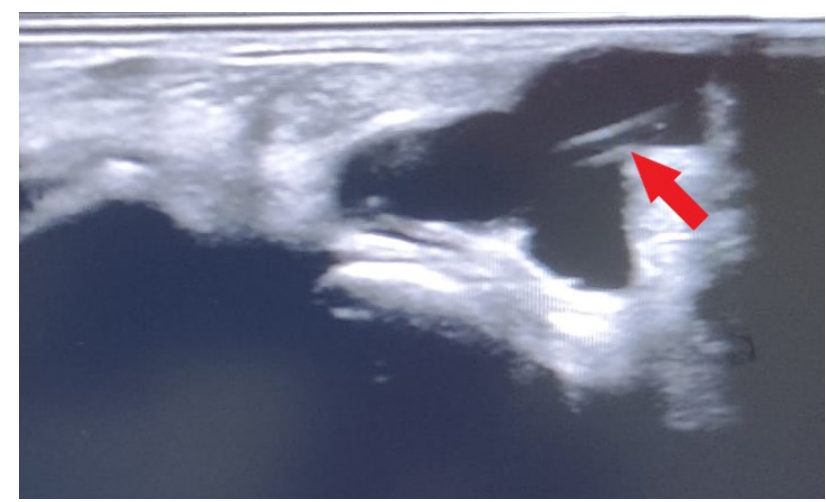

Figure 2. Ultrasonographic view of a wrist ganglion cyst

Aspiration technique: Diagnostic US was performed (Esaote MyLabSix ultrasound system device and a 9-12 $\mathrm{MHz}$ 12L3 linear probe) by a radiologist trained in interventional radiology. Once aseptic conditions were obtained, the skin was anesthetized with $1 \%$ Lidocaine solution. A 16-gauge cannula was introduced into the cavity, and the entire cyst content was removed when possible. Multiple punctuations were performed to enhance the shrink of the cyst wall (Figure 2).

Follow-up: A compressive bandage was used for the first two weeks after the intervention. All patients were advised to apply ice and elevate the affected wrist for the first week. Patients were seen in the outpatient clinic in the second week, first month, $2^{\text {nd }}, 3^{\text {rd }}$, and $6^{\text {th }}$ month after the intervention. At the last follow-up, patients were re-evaluated. The Quick Disabilities of the Arm, 
Table 1: Descriptive statistic and comparison results for the studied characteristics

\begin{tabular}{|c|c|c|c|c|}
\hline & $\begin{array}{l}\text { Study population } \\
(\mathrm{n}=46)\end{array}$ & $\begin{array}{l}\text { Group S } \\
(n=24)\end{array}$ & $\begin{array}{c}\text { Group A } \\
(n=22)\end{array}$ & $\begin{array}{c}\mathrm{p} \\
\text { value }\end{array}$ \\
\hline $\begin{array}{l}\text { Age (Years) } \\
{[\text { Mean } \pm \text { SD] }}\end{array}$ & $33.6 \pm 11.9$ & $33.45 \pm 10.08$ & $33.90 \pm 13.85$ & 0.817 \\
\hline $\begin{array}{l}\text { Gender } \\
\text { (Female: } \\
\text { male) }\end{array}$ & $31: 15(67.4 \%: 32.6 \%)$ & 17: $7(70.8 \%: 19.1 \%)$ & 14: $8(63.6 \%: 36.4 \%)$ & 0.603 \\
\hline $\begin{array}{l}\text { Side } \\
\text { (Right: Left) }\end{array}$ & $26: 20(56.5 \%: 43.4 \%)$ & $14: 10(58.3 \%: 41.6 \%)$ & $12: 10(54.5 \%: 45.5 \%)$ & 0.796 \\
\hline $\begin{array}{l}\text { Follow-up } \\
\text { (Months) } \\
{[\text { Mean } \pm \mathrm{SD}]}\end{array}$ & $11.04 \pm 4.51$ & $10.91 \pm 4.11$ & $11.18 \pm 5.01$ & 0.982 \\
\hline $\begin{array}{l}\text { Cyst location } \\
\text { (Volar: } \\
\text { Dorsal) }\end{array}$ & 15: $31(32.6 \%: 67.4 \%)$ & 8: $16(33.3 \%: 66.7 \%)$ & $7: 15$ (31.8: 68.25) & 0.913 \\
\hline $\begin{array}{l}\text { Duration of } \\
\text { cyst } \\
\text { (Months) } \\
{[\text { Mean } \pm \text { SD] }}\end{array}$ & $5.95 \pm 2.48$ & $6.66 \pm 2.85$ & $5.18 \pm 1.76$ & 0.084 \\
\hline
\end{tabular}

SD: Standard Deviation

Shoulder, and Hand (DASH) questionnaire was used to determine the clinical status of the patients. The Quick DASH score is a selfadministered patient-reported outcome measure that measures the function and disability of the affected upper extremity. It consists of 11 questions with maximum points (100) representing high disability and minimum point (0) representing no disability. Also, recurrence and complications were recorded. The routine US was not performed at the last follow-up visit. When there was doubt about the recurrence of the cyst, the diagnosis of recurrence was made based on the US examination. Clinical scores, recurrence rates, and complications were recorded and compared between the patients who received surgery (Group S) and aspiration (Group A). Also, we divided the patients as recurrence and no recurrence independent from the treatment method, and we compared the Quick DASH scores between those patients.

Statistical analysis: The mean, minimum, maximum, frequency, ratio, and standard deviation (SD) values described the data. The Kolmogorov-Smirnov test was used to determine the distribution of data. The Chi-square test compared two categorical variables, and the Mann Whitney $U$ test was used to compare two independent quantitative data. A p-value of less than 0.05 was considered statistically significant. All statistical analyses were performed using IBM
SPSS for Windows, version 22 (IBM Corp., Armonk, NY, USA).

\section{Results}

Forty-six patients were included in the study with a mean age of $33.6 \pm 11.9$ years. 24 patients in Group S (17 female, 7 male) and 22 patients in Group A (14 females, 8 male). Further demographic details of the patients are presented in Table 1. The mean quick DASH score was $11.25 \pm 2.90$ in Group $S$ and $11.90 \pm 2.70$ in Group A $(p=0.301)$. However, the clinical results were similar between the two groups, though the recurrence rate was significantly higher in Group A $(12.5 \%$ vs. $45.45 \%, p=0.021)$. We have also divided the patients as recurrence $(n=13)$ and no recurrence $(n=33)$ independent from the treatment and found no difference in terms of the Quick DASH score $(p=0.711)$. There was no major complication in both groups during the follow-up period. However, superficial infection was observed in one patient (4.1\%) in Group S, and that patient was treated with oral antibiotics. Also, one patient $(4.1 \%)$ in Group $S$ had numbness around the incision, which healed at the third postoperative month. One patient in Group A $(4.5 \%)$ experienced vasovagal syncope during the procedure. That patient recovered without treatment. 


\section{Discussion}

The main finding of the current study was that the clinical results and recurrence rates of US-guided aspiration and open excision for the wrist ganglion cysts were similar during the short-term period. Also, no major complication was seen in either of the two groups. Aspiration of wrist ganglions is a quick, time-saving, and practical procedure performed in the outpatient clinic. In their study, Kurkis et al. (11) analyzed the recurrence rates of the patients who received aspiration under US guidance and blind. They found that US-guided aspiration does not reduce the recurrence rate. They also reported similar Quick DASH scores with a mean of 2.9 years. Heat et al. reported $52.4 \%$ recurrence after aspiration of ganglion cysts, and they found that long-term satisfaction of the patients was high independent of whether the cyst recurred or not. We found $45.45 \%$ recurrence in the aspiration group with a mean $11.18 \pm 5.01$ months follow-up. The recurrence rate of our study seems slightly less than the literature. The shorter follow-up period may explain this difference. Because of high rates of recurrence, many authors proposed different techniques to reduce recurrence after aspiration. Injection of corticosteroid, sclerosing agents after injection, injection of hyaluronic acid before aspiration, performing multiple punctures on cyst wall, and splinting after aspiration have been proposed. Still, none of those techniques have proven advantages over simple aspiration (13). However, we performed multiple punctuations on the cyst wall and splinting (to reduce swelling and pain rather than recurrence) based on our clinical experience. Surgical excision is accepted as the gold standard treatment for wrist ganglions. In their randomized controlled study, Khan et al. (14) compared the open surgical excision and aspiration and corticosteroid injection of wrist ganglions. They report that the surgery group's success rate (no recurrence) was significantly higher $(94.4 \%$ vs. 61.1\%). Our findings were consistent with Khan et al. (14); the recurrence rates were lower in the surgery group. However, functional status was similar. The reflection of recurrence on patient satisfaction and functional status is controversial. Some authors report that recurrence does not affect patient satisfaction (15), while Kurkis et al. (11) report that the patients who experienced recurrence had a worse Quick DASH score. However, we found no relation between the Quick DASH score and recurrence. Although open excision offers a low recurrence rate, it has some risks such as neuropraxia, wound infection, vascular damage, keloid formation $(12,13)$. In our study, we did not observe vascular injury or permanent nerve damage. We observed a superficial infection and neuropraxia in the surgery group, and both patients healed with conservative measures. We did not observe any significant complications in the surgery group. We recommend surgery in wrist ganglion cysts based on low recurrence rates if the patient is fit for the surgery. Patients with comorbidities may be suitable for US-guided aspiration. Also, surgeons must be aware of surgical complications. We recommend using atraumatic sutures and proper skin incisions to reduce keloid formations. Also, risk factors for surgical site infection should be closely monitored preoperatively such as diabetes. Intraoperative complications can be reduced by careful dissection to avoid iatrogenic neurovascular or ligament injury. The study has some limitations. First, this was a retrospective study which may cause selection bias, and lack of preoperative functional scores may cause misjudgment about the effectiveness of the treatment. Second, the followup period was relatively short, and more extended follow-up periods may change the recurrence rates and patient satisfaction. Still, it should be noted that longer follow-up may also be a source of bias because the cysts may disappear spontaneously after a certain period. Third, we did not perform the US on all patients after interventions, which may have caused us to miss some recurrences. Last, the study population was relatively low, causing the difference in the clinical outcomes not to reach a statistically significant level.

\section{Conclusion}

Both US-guided aspiration and open excision were associated with similar functional outcomes, but the aspiration group had higher recurrence rates. The recurrence did not change functional outcomes. As a result, us-guided cyst aspiration can be used as an alternative method to surgery. The choice of treatment should be individualized based on patients' characteristics and expectations. Conflict of interest: The authors declare no conflict of interest to disclose.

Ackowledgement: None

Funding: The authors received no financial support.

Ethical Approval: Sivas Cumhuriyet University ethical board. Date: 10.02.2021, Approval number: 2021-02/33 
Authors contributions: ET: conceived and designed the study; ET, SO: developed the study protocol, collected the data, ET, SO: analyzed and interpreted the data; SO: supervised the study.

\section{References}

1. Memon F, Abbas R, Khan MA, Quraishy MS. Aspiration combined with seton insertion for treatment of wrist ganglions. J Surg Pak 2007; 3: 121-123.

2. Mehrabani D, Tabei S, Heydari S, Shamsina S, Shokrpour N, Amini M, et al. Cancer occurrence in Fars province, southern Iran. Iran Red Crescent Med J 2008; 10(4): 314322.

3. Gude W, Morelli V. Ganglion cysts of the wrist: pathophysiology, clinical picture, and management. Current reviews in musculoskeletal medicine 2008; 1(3-4): 205211.

4. Zhang A, Falkowski AL, Jacobson JA, Kim SM, Koh SH, Gaetke-Udager K. Sonography of Wrist Ganglion Cysts: Which Location Is Most Common? J Ultrasound Med 2019; 38(8): 2155-2160.

5. Meena S, Gupta A. Dorsal wrist ganglion: Current review of literature. J Clin Orthop Trauma 2014; 5(2): 59-64.

6. Kuliński S, Gutkowska O, Mizia S, Martynkiewicz J, Gosk J. Dorsal and volar wrist ganglions: The results of surgical treatment. Adv Clin Exp Med 2019; 28(1): 95-102.

7. Gitto S, Lee SC, Miller TT. Ultrasoundguided percutaneous treatment of volar radiocarpal ganglion cysts: Safety and efficacy. J Clin Ultrasound 2019; 47(6): 339344.

8. Sharma A, Mudgal M, Kushwah N, Singh N. Comparative Study between Surgical Excision Verses Aspiration and Injection of Sclerosant in Wrist Ganglion Cyst. J Dent Med Science 2019; 18(4): 36-40.

9. Sinha MK, Mishra P, Mishra TS, Barman A. Aspiration and steroid injection in ganglion cysts: An ultrasound guided evaluation of the response. J Clin Orthop Trauma 2019; 10: 252-257.

10. Cluts LM, Fowler JR. Factors Impacting Recurrence Rate After Open Ganglion Cyst Excision. Hand 2020; 26: 1-5.

11. Kurkis G, Anastasio A, DeVos M, Gottschalk MB. Ultrasound-Guided Aspiration Does Not Reduce the Recurrence Rate of Ganglion Cysts of the Wrist. J Wrist Surg 2019; 8(2): 100-113.

12. Head L, Gencarelli JR, Allen M, Boyd KU. Wrist ganglion treatment: systematic review and meta-analysis. J Hand Surg Am 2015; 40(3): 546-553.

13. Meena S, Gupta A. Dorsal wrist ganglion: Current review of literature. Journal of clinical orthopaedics and trauma 2014; 5(2): 59-64.

14. Khan PS, Hayat H. Surgical excision versus aspiration combined with intralesional triamcinolone acetonide injection plus wrist immobilization therapy in the treatment of dorsal wrist ganglion; a randomized controlled trial. J Hand Microsurg 2011; $3(2): 55-57$.

15. Head L, Allen M, Boyd KU. Long-term outcomes and patient satisfaction following wrist ganglion aspiration. Plast Surg. 2015; 23(1): 51-53. 